\title{
COMPARATIVE STUDY ON THE PRODUCTIVITY AND PROFITABILITY OF COMMERCIAL BROILER, COCKEREL OF A LAYER STRAIN AND CROSS-BRED (RIR $\curvearrowright$ FAYOUMI $\uparrow)$ CHICKS
}

\author{
P. K. Sarkar ${ }^{1}$, S. D. Chowdhury ${ }^{1}$, M. H. Kabir ${ }^{1}$ and P. K. Sarker ${ }^{2}$
}

\begin{abstract}
An experiment was conducted to compare the productivity and profitability of commercial broiler, cockerel and cross-bred $\left(\mathrm{F}_{1} \mathrm{RIR} \hat{\delta} \times\right.$ Fayoumi $\left.{ }_{+}\right)$chicks up to target body weights of 850,1000 and $1250 \mathrm{~g}$. Two hundred sixteen birds of 3 genotypes each of 72 birds having 18 chicks in each replication were considered. Commercial broiler starter diet was fed to experimental birds ad libitum. Similar care and management were provided to birds of all treatment groups. Commercial broilers attained the target weights of 850,1000 and $1250 \mathrm{~g}$ at the age of 21,24 and 28 days respectively whereas cockerels attained weights close to those targets at 56, 63 and 74 days respectively and in the case of cross-breds, the days were 63, 77 and 90 for those target weights respectively. Feed conversion ratio (FCR) was best in broilers, followed by cockerels and cross-bred chicks respectively. The highest mortality $(8.3 \%)$ was found in cross-bred group when reared up to target weight of $1250 \mathrm{~g}$. The mortality of broiler was $1.4 \%$ and no bird was died in cockerel group. Broiler was most profitable $(21.11 \mathrm{Tk} / \mathrm{kg}$ live bird) at the target weight of $1250 \mathrm{~g}$ whereas profit from cockerel varied little $(21.78,21.07$ and $21.63 \mathrm{Tk} / \mathrm{kg}$ live bird against the target weights of 850,1000 and $1250 \mathrm{~g}$ respectively) amoung target weights. Therefore, appropriate weight to market these birds was at $850 \mathrm{~g}$ to minimize the risk of diseases and other management works. Marketing of cross-bred chicks was most profitable $(8.43 \mathrm{Tk} / \mathrm{kg}$ live bird) at $850 \mathrm{~g}$ target weight and loss was incurred when rearing was continued up to $1250 \mathrm{~g}$. On the basis of results of productivity, it was concluded that commercial broiler, cockerel and cross-bred chicks could be reared upto 28, 56 and 63 days respectively to reach target weights close to 1250,850 and $850 \mathrm{~g}$ respectively to obtain maximum profit.
\end{abstract}

Key words : Broiler, Cockerel, Cross-bred, Productivity, Profitability

\section{Introduction}

Broiler is an important part of commercial poultry enterprise. The modern broiler chicken is fast growing, efficient and can rapidly fulfill the shortage of protein requirement since it can be produced at least possible time as compared to other meat producing animals. To reduce the shortage of animal protein in the country, broiler can play an important role. Male chicks,

\footnotetext{
${ }^{1}$ Department of Poultry Science, Bangladesh Agricultural University, Mymensingh-2202, Bangladesh

${ }^{2}$ Instructor (Poultry Rearing and Farming), Hosenabad Technical School and College, Daulatpur, Kushtia, Bangladesh
}

(Received : March 29, 2008) 
Bang. J. Anim. Sci. 2008, 37(2)

popularly known as cockerels constitutes $50 \%$ of day-old layer chicks. Such chicks have become an indispensable component of poultry development with the rapidly increasing trends of commercial layer farming in Bangladesh. In 2005, about 0.212 million layer parent stocks were produced in the country that produced 19.08 million day-old chicks (DOC) per year (BRAC, 2005; DLS, 2005). The layer farmers buy female chicks from the hatchery and a significant number of cockerels are mostly sold at a low price or sometimes destroyed at day-old when there remains no scope for marketing. The scope for utilizing these cockerels as a source of poultry meat is high because many consumers prefer cockerel equally to that of indigenous chicken and many people consider that it is tastier than the broiler meat. Utilization of these cockerels through smallholder family poultry farming helps control environment pollution, increase nutrition, generates income and self-employment in the rural community. Consumers' choice, lower chick price, lower mortality and morbidity, lower management cost, lower initial investment, better market demand, low abdominal fat, more organoleptic preference, family labor utilization and easy management are the strategic advantages for cockerel rearing.

Sonali, the $F_{1}$ cross-bred of RIR $\hat{\sigma} \times$ Fayoumi $q$ has been taking place besides the indigenous hens due to their adaptability and acceptability in the climatic conditions of Bangladesh (Anisuzzaman, 1988). Such cross-bred chicken has already been proved worth in production performances in semi-scavenging system under village condition of Bangladesh (Amber et al. 1999). Considering the environmental factors e.g., rainfall, housing and economic traits as survivability, rapid growth of male chicks as well as female's egg production, this cross-bred was recommended to rear for small-holder poultry farming in Bangladesh (Amber, 2000). Cross-bred progenies were superior to purebred in terms of growth rate, meat quality, body weight and feed conversion (Masic and Khalifah, 1965). Sonali is suggested for rearing at village levels because of its low cost, small size, suitability for rearing under Bangladesh environment particularly in rural areas. Therefore, farming with this cross-bred chicken by the smallholder village poultry farmers in Bangladesh may ensure sustainable poultry production in the country as well as to improve the economic and nutritional status of the people.

It is well known that the demand for small size young chicken is high in the market because of their tenderness and the customers are ready to pay more for it. Although much of the previous attempts of the researchers have been directed to explore advantages of rearing broiler, cockerel or cross-bred in Bangladesh separately, comparative study among them with regard to their productivity and profitability in different weight groups has so far received little attention. So, the present study was designed to compare the growth rate, feed intake, feed conversion efficiency, livability, comparative cost, return and profitability among commercial broiler, cockerel and cross-bred (RIR $\hat{\sigma} \times$ Fayoumi +) chicks in different weight groups. 


\section{Materials and Methods}

\section{Experimental birds and their source}

Rhode Island Red (RIR) male and Fayoumi female chickens at the ratio of 1:6 were reared, crossed and hatching eggs were incubated in the Hatchery of Bangladesh Agricultural University Poultry Farm, Mymensingh to obtain day-old cross-bred (Sonali) chicks. Seventy two cross-bred chicks of uniform size were selected. Seventy two, each of Shaver 579 dayold cockerels and Cobb 500 day-old commercial broilers were procured from the hatchery of Index group, Rajendrapur, Gazipur.

\section{Initial care, feeding and watering of birds}

The chicks were supplied with $5 \%$ glucose solution on arrival in the experimental shed to overcome transportation stress. For the first three days, broiler starter (CP 23.1\%, CF 5.9\%, EE 4.4\% and Ash 6.1\%) of Aftab Feed Mill (Aftab Bahumukhi Farms Limited, Bhagalpur, Bajitpur, Kishoregonj) was supplied on clean newspaper in the form of crumble and then on trays up to one week. After one week, broiler starter feed (CP 24.8\%, CF 5.5\%, EE 4.3\% and Ash $5.9 \%$ ) of Nourish Poultry and Hatchery Limited was supplied to round feeders throughout the production period. All birds were fed and watered ad libitum. Multi-vitamin premix (Megavit WS; Novartis Animal Health, Dhaka, Bangladesh) was supplied through drinking water to each group of birds. Moreover, vitamin $\mathrm{C}$ was given through drinking water to all birds when the environmental temperature went above $30^{\circ} \mathrm{C}$. Feed and water were supplied three times per day during the $1^{\text {st }}$ week and then twice daily up to the end of the production period.

\section{Brooding and lighting}

A 100 watt bulb was hung in each experimental pen for brooding the birds. The room temperature was $29-34^{\circ} \mathrm{C}$ during the first week. After first week, the environmental temperature increased excessively and it was $30-39^{\circ} \mathrm{C}$ up to $3^{\text {rd }}$ week. So, no extra heat was required for the chicks. During the first and second week, 24 hours lighting was confirmed and it was decreased at the rate of one hour in each subsequent week up to target weights set up for each genotype.

\section{Vaccination}

All birds were vaccinated against Ranikhet disease only. Baby Chick Ranikhet Disease Vaccine (BCRDV) was administrated one drop in each eye at $4^{\text {th }}$ and $25^{\text {th }}$ days of chicken. Broilers were administrated vaccine at $4^{\text {th }}$ day only and no further vaccines were given due to early achievement of target weight (28 days of rearing). 
Bang. J. Anim. Sci. 2008, 37(2)

\section{Biosecurity measures}

Adequate hygienic measures and appropriate sanitation programmes were carried out during the experimental period. The experimental area was restricted by making fences and was kept open only to researcher, supervisor and workers related to the experiment by following special care. Before entrance into the experimental shed, special hygienic and sanitary measures were taken to avoid the entrance of diseases and germs from outside. Hands and feet were washed with soap; feet were dipped in a water bath containing disinfectant and clean apron was worn as a part of hygienic measurement. Hygienic management of feeding, watering, vaccination programs and litter management were taken during the experimental period. Disinfectants (Virkon ${ }^{\circledR}$ S; Antec Internatinal, England, U.K.); and bleaching powder) were regularly sprayed on the road and surroundings of the experimental shed to prevent disease outbreak and kerosene was spread carefully to control ant.

\section{Growth target, record keeping and statistical analyses}

Growth targets for each genotype of birds were fixed at 850, 1000 and 1250g depending on market demand. Weekly body weight and feed intake and the days when birds reached weights close to targets $(850,1000$ and $1250 \mathrm{~g})$ were recorded. Body weight gain, feed consumption and FCR were calculated. The growth rate, feed consumption and expenses and returns were statistically analyzed by using "MSTAT" statistical programme in a completely randomized design involving 3 treatments (commercial broiler, cockerel and cross-bred) each of 4 replications by computing analysis of variance (ANOVA). Treatment means for each parameter were compared using least significant difference (LSD) test.

\section{Results and Discussion}

The performance of commercial broiler, cockerel and cross-bred (RIR $\widehat{\sigma} \times$ Fayoumi + ) chicks up to target weights is shown in Table 1.

\section{Body weight}

Broiler reached to each target weight earlier than cockerel and cross-bred chicks, as would be expected. The body weight of broiler (Cobb 500) was more or less close to the standard weights as indicated by Cobb Breeding Company Limited (Cobb-500, Commercial Broiler Management Guide, 2004). According to data published by the Breeding Company, the Cobb 500 achieves $765 \mathrm{~g}$ weight at 21 days and $1259 \mathrm{~g}$ at 28 days where as the broiler birds in this study achieved $837.5 \mathrm{~g}$ at 21 days and $1328.3 \mathrm{~g}$ at 28 days. Thus the results obtained in this study were close to those reported by the original breeder.

In the present experiment, the cockerels achieved $1023.6 \mathrm{~g}$ and weight gain was $993.4 \mathrm{~g}$ at 63 days against the target weight of $1000 \mathrm{~g}$. The achieved body weight and body weight gain of 
cockerels were more or less similar to an earlier report of Roy et al. (2006), who investigated the productive performance of cockerels to different target weights. They found weights close to 500, 750 and $1000 \mathrm{~g}$ at 42,53 and 63 days old respectively and the average live weight gain was 492.9, 750.3 and $966.4 \mathrm{~g}$ for those target weights respectively. Thus, both the body weight and body weight gain as obtained in this study at 63 days agreed well with Roy et al. (2006).

In this trial, cross-bred birds attained 850,1000 and $1250 \mathrm{~g}$ at 63,77 and 90 days respectively whereas Chowdhury (2003) conducted an experiment with cross-bred chickens and reported 750,1000 and $1250 \mathrm{~g}$ at 98, 126 and 147 days respectively. Islam et al. (2006) found $928 \mathrm{~g}$ live weight at 84 days and Azharul et al. (2005) found 1001g live weight at 56 days old.

\section{Feed consumption}

The differences in the amount of feed consumed and FCR in each target weight $(850,1000$ and $1250 \mathrm{~g})$ were highly significant $(\mathrm{P}<0.01)$. For each target weight group, commercial broilers consumed less feed than cockerels and cross-bred birds. The cross-breds consumed the highest amount of feed. FCR was best in broilers in comparison with cockerel and crossbred chicks. Feed consumption and FCR of broiler (Cobb 500) were slightly higher than the data indicated by the Cobb Breeding Company Limited. According to the Breeding Company, birds consume 1003 and $1836 \mathrm{~g}$ feed respectively up to 21 and 28 days with corresponding FCR value of 1.31 and 1.46 respectively (Cobb-500, Commercial Broiler Management Guide, 2004). In this experiment, broiler consumed 1183.5 and $2151.4 \mathrm{~g}$ feed with FCR 1.41 and 1.62 up to 21 days and 28 days respectively.

The feed consumption and FCR of cockerels against $1000 \mathrm{~g}$ weight group were $2348.9 \mathrm{~g}$ and 2.30 respectively. These results agreed well with those of Roy et al. (2006) who reported $2321.7 \mathrm{~g}$ feed intake with FCR value of 2.40 against target weight of $1000 \mathrm{~g}$. Haque et al. (2005) found FCR values of 2.61 and 2.70 at 42 days and 70 days of age respectively. Mamun (2003) found a FCR value of 2.60 at 56 days. The result of this experiment was contradictory with the result of Himanshu et al. (2004), who found that FCR ranged from 3.11 to 4.27 at 42 days of age. The reason for such discrepancies in results might be due to the differences in the compositions of diets used and/or managemental procedures followed for the study.

The feed consumption and FCR of cross-bred birds were not in agreement with the results of Chowdhury (2003), whose findings were 4360, 6810 and 7830g; and 5.81, 6.80, 6.26 for weight groups of 750,1000 and $1250 \mathrm{~g}$ respectively. This may have been due to the fact that Chowdhury (2003) fed home-made feed and allowed the birds for scavenging whereas birds of this trial consumed industrial high proteinous broiler feeds. The FCR value was close to the report of Rahman et al. (2004), who found 2.9 and 3.1 at 56 and 84 days respectively. 
Bang. J. Anim. Sci. 2008, 37(2)

\section{Survivability}

No significant difference $(\mathrm{P}>0.05)$ in survivability up to rearing was found among the type of birds. The survivability was quite satisfactory up to $1000 \mathrm{~g}$ target weight for all types of birds. When reared up to $1250 \mathrm{~g}$ target, survivability decreased for cross-bred birds. At 89 days, cross-bred chicks were affected by Infectious Bursal Disease (IBD) and 6 birds died of such problem which brought down survivability to $92 \%$. External symptoms were loss of appetite, whitish watery droppings, dull appearance and post mortem lesions were swollen bursa, edema and haemorrhages in the thigh and breast muscle. The mortality of cross-breds was $8.3 \%$ and was close to the earlier report of Azharul et al. (2005), who found $7.8 \%$ mortality in the same type of birds during a period of 56 days. Of course, vaccination for IBD was not practiced in this study.

\section{Economics of production}

Table 2 shows the economics of producing commercial broiler, cockerel and cross-bred chicks grown to different target weights. The cost items included the cost of chick, feed, litter, vitamins, vaccination, labour, light, electricity and miscellaneous items. Expenses involved for dead birds were included in total cost and net profits were calculated on live weight of bird basis. The differences in total cost and net profits were highly significant $(\mathrm{P}<0.01)$ in each weight group $(850,1000$ and $1250 \mathrm{~g})$. Feed constituted the major cost as would be expected. It was found that total cost (Tk/ kg live bird) was always highest in crossbred, intermediate in cockerel and lowest in commercial broiler in all target weights. The market price of broiler, cockerel and cross-bred were Tk. 85, 120 and 130 per kg live weight respectively. Table 2 shows that broiler attained highest profit in $1250 \mathrm{~g}$ weight group; profit was more or less similar in every weight group for cockerel. Profit from cross-bred was highest in $850 \mathrm{~g}$ weight group and rearing them up to $1250 \mathrm{~g}$ weight incurred loss (Tk. 11.34 per kg bird).

Profit from commercial broiler was found maximum $(21.11 \mathrm{Tk} / \mathrm{kg}$ live bird) in the target weight of 1250g. Ahmed (1999) found maximum profit of $22.14 \mathrm{Tk} / \mathrm{bird}$ in Arbor Acre broilers. Another report of the same author also stated maximum profit of Tk. 19.47 in the same type of bird comparing with those of i757 (Tk. 15.92) and Starbro (Tk. 15.23) respectively. Since profit from different genotypes of birds in this experiment was calculated as $\mathrm{Tk} / \mathrm{kg}$ live bird, the results could not be related to the findings of those earlier studies. Profits (Tk/kg live bird) from cockerel were 21.78, 21.07 and 21.63 for target weight of 850, 1000 and $1250 \mathrm{~g}$ respectively. This result was close to the data previously reported by Roy et al. (2006), who found profit (Tk/ kg live birds) as Tk. 19.35 and Tk. 22.28 from target weight group of 750 and $1000 \mathrm{~g}$ respectively.

Profits (Tk/kg live bird) from cross-bred were Tk. 8.43 and 1.88 for target weight group of 850 and $1000 \mathrm{~g}$ respectively. The experiment showed that profitability decreases with the increase of rearing time in case of cockerel rearing. A loss of $11.34 \mathrm{Tk} / \mathrm{kg}$ bird was incurred for cross-bred when reared up to $1250 \mathrm{~g}$ weight. This was due to mortality, excess labour cost and management cost involved for rearing cross-bred for such a longer period. 
Table 1. Performance of broiler, cockerel and cross-bred chicks up to target body weights

\begin{tabular}{|c|c|c|c|c|c|c|c|c|c|c|c|c|}
\hline \multirow[t]{3}{*}{ Parameters } & \multicolumn{9}{|c|}{ Body weights targets (g) } & \multirow{2}{*}{\multicolumn{3}{|c|}{$\begin{array}{c}\text { Statistical comparisons } \\
\text { among type of birds }\end{array}$}} \\
\hline & \multicolumn{3}{|c|}{850} & \multicolumn{3}{|c|}{1000} & \multicolumn{3}{|c|}{1250} & & & \\
\hline & Broiler & Cockerel & $\begin{array}{l}\text { Cross- } \\
\text { bred }\end{array}$ & Broiler & Cockerel & $\begin{array}{l}\text { Cross- } \\
\text { bred }\end{array}$ & Broiler & Cockerel & $\begin{array}{l}\text { Cross- } \\
\text { bred }\end{array}$ & $850 \mathrm{~g}$ & $\begin{array}{c}1000 \\
\mathrm{~g}\end{array}$ & $1250 \mathrm{~g}$ \\
\hline $\begin{array}{l}\text { Initial body } \\
\text { weight }(\mathrm{g})\end{array}$ & $\begin{array}{l}42.9^{\mathrm{a}} \\
\pm 2.17\end{array}$ & $\begin{array}{l}30.3^{\mathrm{b}} \\
\pm 0.29\end{array}$ & $\begin{array}{c}30^{\mathrm{b}} \\
\pm 0.47\end{array}$ & $\begin{array}{l}42.9^{\mathrm{a}} \\
\pm 2.17\end{array}$ & $\begin{array}{l}30.3^{\mathrm{b}} \\
\pm 0.29\end{array}$ & $\begin{array}{c}30^{\mathrm{b}} \\
\pm 0.47\end{array}$ & $\begin{array}{l}42.9^{\mathrm{a}} \\
\pm 2.17\end{array}$ & $\begin{array}{l}30.3^{\mathrm{b}} \\
\pm 0.29\end{array}$ & $\begin{array}{c}30^{\mathrm{b}} \\
\pm 0.47\end{array}$ & $* *$ & $* *$ & $* *$ \\
\hline $\begin{array}{l}\text { Achieved body } \\
\text { weight }(\mathrm{g})\end{array}$ & $\begin{array}{c}837.5^{b} \\
\pm \\
12.93\end{array}$ & $\begin{array}{c}884.7^{\mathrm{a}} \\
\pm 23.73\end{array}$ & $\begin{array}{c}845.8^{b} \\
\pm 13.89\end{array}$ & $\begin{array}{c}1029 \\
\pm \\
23.76\end{array}$ & $\begin{array}{r}1023.6 \\
\pm 14.61\end{array}$ & $\begin{aligned} & 1016 \\
\pm & 14.05\end{aligned}$ & $\begin{array}{l}1328.3^{\mathrm{a}} \\
\pm 11.48\end{array}$ & $\begin{array}{l}1265.3^{\mathrm{ab}} \\
\pm 65.32\end{array}$ & $\begin{array}{l}1237.6^{\mathrm{b}} \\
\pm 31.89\end{array}$ & $* *$ & NS & $*$ \\
\hline Body weight gain (g) & $\begin{array}{c}794.6^{b} \\
\pm \\
10.81\end{array}$ & $\begin{array}{r}854.5^{\mathrm{a}} \\
\pm 23.83\end{array}$ & $\begin{array}{c}815.9^{b} \\
\pm 13.70\end{array}$ & $\begin{array}{c}986.2 \\
\pm \\
23.03\end{array}$ & $\begin{array}{c}993.4 \\
\pm 14.58\end{array}$ & $\begin{array}{c}986.0 \\
\pm 13.66\end{array}$ & $\begin{array}{l}1285.4 \\
\pm 12.39\end{array}$ & $\begin{array}{r}1235.0 \\
\pm 65.44\end{array}$ & $\begin{array}{r}1207.6 \\
\pm 31.91\end{array}$ & $* *$ & NS & NS \\
\hline Feed intake $(\mathrm{g})$ & $\begin{array}{c}1183.5 \\
\mathrm{c} \\
\pm \\
36.17\end{array}$ & $\begin{array}{l}1883.6^{\mathrm{b}} \\
\pm 84.12\end{array}$ & $\begin{array}{l}2517.7^{\mathrm{a}} \\
\pm 58.21\end{array}$ & $\begin{array}{c}1589.6 \\
\mathrm{c} \\
\pm \\
33.76\end{array}$ & $\begin{array}{l}2348.9^{b} \\
\pm 57.36\end{array}$ & $\begin{array}{l}3360.2^{\mathrm{a}} \\
\pm 60.76\end{array}$ & $\begin{array}{l}2151.4^{\mathrm{c}} \\
\pm 52.00\end{array}$ & $\begin{array}{l}3087.8^{b} \\
\pm 61.46\end{array}$ & $\begin{array}{l}4294.2^{\mathrm{a}} \\
\pm 61.24\end{array}$ & $* *$ & $* *$ & $* *$ \\
\hline FCR & $\begin{array}{l}1.414^{\mathrm{c}} \\
\pm 0.06\end{array}$ & $\begin{array}{l}2.129^{b} \\
\pm 0.07\end{array}$ & $\begin{array}{l}2.976^{\mathrm{a}} \\
\pm 0.04\end{array}$ & $\begin{array}{l}1.545^{\mathrm{c}} \\
\pm 0.05\end{array}$ & $\begin{array}{l}2.295^{\mathrm{b}} \\
\pm 0.06\end{array}$ & $\begin{array}{l}3.308^{\mathrm{a}} \\
\pm 0.08\end{array}$ & $\begin{array}{l}1.620^{\mathrm{c}} \\
\pm 0.03\end{array}$ & $\begin{array}{l}2.444^{\mathrm{b}} \\
\pm 0.10\end{array}$ & $\begin{array}{l}3.472^{\mathrm{a}} \\
\pm 0.12\end{array}$ & $* *$ & $* *$ & $* *$ \\
\hline Survivability (\%) & $\begin{array}{c}100 \\
\pm 0.00\end{array}$ & $\begin{array}{c}100 \\
\pm 0.00\end{array}$ & $\begin{array}{c}100 \\
\pm 0.00\end{array}$ & $\begin{array}{c}98.6 \\
\pm 2.78\end{array}$ & $\begin{array}{c}100 \\
\pm 0.00\end{array}$ & $\begin{array}{c}100 \\
\pm 0.00\end{array}$ & $\begin{array}{c}98.6 \\
\pm 2.78\end{array}$ & $\begin{array}{c}100 \\
\pm 0.00\end{array}$ & $\begin{array}{c}91.7 \\
\pm 9.62\end{array}$ & NS & NS & NS \\
\hline Days to target & 21 & 56 & 63 & 24 & 63 & 77 & 28 & 74 & 90 & - & - & - \\
\hline
\end{tabular}

${ }^{a b c}$ Mean values having different superscripts in a row within same weight group differed significantly **, $\mathrm{P}<0.01 ; *, \mathrm{P}<0.05 ; \mathrm{NS}=\mathrm{P}>0.05$ 
Bang. J. Anim. Sci. 2008, 37(2)

Table 2. Economics of producing broiler, cockerel and cross-bred chicks up to target body weights

abc Mean values having different superscripts in a row within a weight group differed significantly; ${ }^{1}$, Miscellaneous cost included cost of transportation and disinfectants; **, $\mathrm{P}<0.01 ; \mathrm{NS}=\mathrm{P}>0.05$; *, Indicate loss.

\begin{tabular}{|c|c|c|c|c|c|c|c|c|c|c|c|c|}
\hline \multirow[t]{3}{*}{ Variables } & \multicolumn{9}{|c|}{ Body weights targets (g) } & \multirow{2}{*}{\multicolumn{3}{|c|}{$\begin{array}{c}\text { Statistical } \\
\text { comparisons among } \\
\text { types }\end{array}$}} \\
\hline & \multicolumn{3}{|c|}{850} & \multicolumn{3}{|c|}{1000} & \multicolumn{3}{|c|}{1250} & & & \\
\hline & Broiler & $\begin{array}{c}\text { Cocker } \\
\text { el }\end{array}$ & $\begin{array}{c}\text { Cross- } \\
\text { bred }\end{array}$ & Broiler & \begin{tabular}{|c|} 
Cocker \\
el
\end{tabular} & $\begin{array}{l}\text { Cross- } \\
\text { bred }\end{array}$ & Broiler & $\begin{array}{c}\text { Cocker } \\
\text { el }\end{array}$ & $\begin{array}{c}\text { Cross- } \\
\text { bred }\end{array}$ & $850 \mathrm{~g}$ & $1000 \mathrm{~g}$ & $1250 \mathrm{~g}$ \\
\hline Chick cost (Tk/chick) & $\begin{array}{l}20.00 \\
\pm 0.00\end{array}$ & $\begin{array}{c}12.00 \\
\pm 0.00\end{array}$ & $\begin{array}{c}10.00 \\
\pm 0.00\end{array}$ & $\begin{array}{l}20.00 \\
\pm 0.00\end{array}$ & $\begin{array}{l}12.00 \\
\pm 0.00\end{array}$ & $\begin{array}{c}10.00 \\
\pm 0.00\end{array}$ & $\begin{array}{l}20.00 \\
\pm 0.00\end{array}$ & $\begin{array}{l}12.00 \\
\pm 0.00\end{array}$ & $\begin{array}{c}10.00 \\
\pm 0.00\end{array}$ & NS & NS & NS \\
\hline Feed cost (Tk/bird) & $\begin{array}{l}23.91^{\mathrm{c}} \\
\pm 0.73\end{array}$ & $\begin{array}{l}38.80^{\mathrm{b}} \\
\pm 1.73\end{array}$ & $\begin{array}{l}51.87^{\mathrm{a}} \\
\pm 1.20\end{array}$ & $\begin{array}{l}32.18^{\mathrm{c}} \\
\pm 0.69\end{array}$ & $\begin{array}{l}48.39^{\mathrm{b}} \\
\pm 1.18\end{array}$ & $\begin{array}{l}69.89^{\mathrm{a}} \\
\pm 1.26\end{array}$ & $\begin{array}{l}43.46^{\mathrm{c}} \\
\pm 1.05\end{array}$ & $\begin{array}{l}63.92^{\mathrm{b}} \\
\pm 1.27\end{array}$ & $\begin{array}{l}97.23^{\mathrm{a}} \\
\pm 9.95\end{array}$ & $* *$ & $* *$ & $* *$ \\
\hline $\begin{array}{l}\text { Feed cost }(\mathrm{Tk} / \mathrm{kg} \\
\text { bird) }\end{array}$ & $\begin{array}{l}28.56^{\mathrm{c}} \\
\pm 1.25\end{array}$ & $\begin{array}{l}43.86^{\mathrm{b}} \\
\pm 1.54\end{array}$ & $\begin{array}{l}61.32^{\mathrm{a}} \\
\pm 0.85\end{array}$ & $\begin{array}{l}31.29^{c} \\
\pm 1.01\end{array}$ & $\begin{array}{l}47.28^{\mathrm{b}} \\
\pm 1.27\end{array}$ & $\begin{array}{l}68.81^{\mathrm{a}} \\
\pm 1.66\end{array}$ & $\begin{array}{l}32.72^{\mathrm{c}} \\
\pm 0.68\end{array}$ & $\begin{array}{l}50.59^{\mathrm{b}} \\
\pm 2.13\end{array}$ & $\begin{array}{l}78.67^{\mathrm{a}} \\
\pm 9.06\end{array}$ & $* *$ & $* *$ & $* *$ \\
\hline Litter cost (Tk/bird) & $\begin{array}{c}2.78 \\
\pm 0.00\end{array}$ & $\begin{array}{c}2.78 \\
\pm 0.00\end{array}$ & $\begin{array}{c}2.78 \\
\pm 0.00\end{array}$ & $\begin{array}{c}2.78 \\
\pm 0.00\end{array}$ & $\begin{array}{c}2.78 \\
\pm 0.00\end{array}$ & $\begin{array}{c}2.78 \\
\pm 0.00\end{array}$ & $\begin{array}{c}2.78 \\
\pm 0.00\end{array}$ & $\begin{array}{c}2.78 \\
\pm 0.00\end{array}$ & $\begin{array}{c}2.78 \\
\pm 0.00\end{array}$ & NS & NS & NS \\
\hline $\begin{array}{l}\text { Vitamin cost } \\
\text { (Tk/bird) }\end{array}$ & $\begin{array}{c}1.11 \\
\pm 0.00\end{array}$ & $\begin{array}{c}1.75 \\
\pm 0.00\end{array}$ & $\begin{array}{c}2.3 \\
\pm 0.00\end{array}$ & $\begin{array}{c}1.49 \\
\pm 0.00\end{array}$ & $\begin{array}{c}2.21 \\
\pm 0.00\end{array}$ & $\begin{array}{c}3.13 \\
\pm 0.00\end{array}$ & $\begin{array}{c}2.05 \\
\pm 0.00\end{array}$ & $\begin{array}{c}2.85 \\
\pm 0.00\end{array}$ & $\begin{array}{c}4.32 \\
\pm 0.00\end{array}$ & NS & NS & NS \\
\hline $\begin{array}{l}\text { Vaccination cost } \\
\text { (Tk/bird) }\end{array}$ & $\begin{array}{c}0.21 \\
\pm 0.00\end{array}$ & $\begin{array}{c}0.42 \\
\pm 0.00\end{array}$ & $\begin{array}{c}0.42 \\
\pm 0.00\end{array}$ & $\begin{array}{c}0.21 \\
\pm 0.00\end{array}$ & $\begin{array}{c}0.42 \\
\pm 0.00\end{array}$ & $\begin{array}{c}0.42 \\
\pm 0.00\end{array}$ & $\begin{array}{c}0.21 \\
\pm 0.00\end{array}$ & $\begin{array}{c}0.42 \\
\pm 0.00\end{array}$ & $\begin{array}{c}0.42 \\
\pm 0.00\end{array}$ & NS & NS & NS \\
\hline Labour cost (Tk/bird) & $\begin{array}{c}4.86 \\
\pm 0.00\end{array}$ & $\begin{array}{c}16.20 \\
\pm 0.00\end{array}$ & $\begin{array}{c}18.63 \\
\pm 0.00\end{array}$ & $\begin{array}{c}5.63 \\
\pm 0.00\end{array}$ & $\begin{array}{l}18.63 \\
\pm 0.00\end{array}$ & $\begin{array}{l}23.50 \\
\pm 0.00\end{array}$ & $\begin{array}{c}6.57 \\
\pm 0.00\end{array}$ & $\begin{array}{l}22.45 \\
\pm 0.00\end{array}$ & $\begin{array}{c}34.34 \\
\pm 0.00\end{array}$ & NS & NS & NS \\
\hline Light cost (Tk/bird) & $\begin{array}{c}1.22 \\
\pm 0.00\end{array}$ & $\begin{array}{c}1.53 \\
\pm 0.00\end{array}$ & $\begin{array}{l}1.53 \\
\pm 0.00\end{array}$ & $\begin{array}{c}1.24 \\
\pm 0.00\end{array}$ & $\begin{array}{c}1.53 \\
\pm 0.00\end{array}$ & $\begin{array}{c}1.83 \\
\pm 0.00\end{array}$ & $\begin{array}{c}1.24 \\
\pm 0.00\end{array}$ & $\begin{array}{c}1.83 \\
\pm 0.00\end{array}$ & $\begin{array}{c}2.00 \\
\pm 0.00\end{array}$ & NS & NS & NS \\
\hline $\begin{array}{l}\text { Electricity cost } \\
\text { (Tk/bird) }\end{array}$ & $\begin{array}{c}4.43 \\
\pm 0.00\end{array}$ & $\begin{array}{r}10.40 \\
\pm 0.00\end{array}$ & $\begin{array}{l}11.80 \\
\pm 0.00\end{array}$ & $\begin{array}{c}4.87 \\
\pm 0.00\end{array}$ & $\begin{array}{l}11.80 \\
\pm 0.00\end{array}$ & $\begin{array}{r}14.60 \\
\pm 0.00\end{array}$ & $\begin{array}{c}5.92 \\
\pm 0.00\end{array}$ & $\begin{array}{l}14.00 \\
\pm 0.00\end{array}$ & $\begin{array}{c}18.76 \\
\pm 0.00\end{array}$ & NS & NS & NS \\
\hline $\begin{array}{l}\text { Miscellaneous cost } \\
(\mathrm{Tk} / \mathrm{bird})^{1}\end{array}$ & $\begin{array}{c}1.00 \\
\pm 0.00\end{array}$ & $\begin{array}{c}3.00 \\
\pm 0.00\end{array}$ & $\begin{array}{c}3.50 \\
\pm 0.00\end{array}$ & $\begin{array}{c}1.52 \\
\pm 0.00\end{array}$ & $\begin{array}{c}3.50 \\
\pm 0.00\end{array}$ & $\begin{array}{c}4.00 \\
\pm 0.00\end{array}$ & $\begin{array}{c}2.03 \\
\pm 0.00\end{array}$ & $\begin{array}{c}4.00 \\
\pm 0.00\end{array}$ & $\begin{array}{c}4.91 \\
\pm 0.00\end{array}$ & NS & NS & NS \\
\hline Total cost (Tk/bird) & $\begin{array}{l}59.52^{\mathrm{c}} \\
\pm 0.73\end{array}$ & $\begin{array}{l}86.88^{\mathrm{b}} \\
\pm 1.73\end{array}$ & $\begin{array}{l}102.82^{\mathrm{a}} \\
\pm 1.20\end{array}$ & $\begin{array}{l}69.92^{\mathrm{c}} \\
\pm 0.69\end{array}$ & $\begin{array}{l}101.25^{\mathrm{b}} \\
\pm 1.18\end{array}$ & $\begin{array}{c}130.14^{\mathrm{a}} \\
\pm 1.20\end{array}$ & $\begin{array}{l}84.25^{\mathrm{c}} \\
\pm 1.05\end{array}$ & $\begin{array}{l}124.25^{\mathrm{b}} \\
\pm 1.27\end{array}$ & $\begin{array}{l}174.76^{\mathrm{a}} \\
\pm 9.95\end{array}$ & $* *$ & $* *$ & $* *$ \\
\hline $\begin{array}{l}\text { Total cost }(\mathrm{Tk} / \mathrm{kg} \\
\text { bird) }\end{array}$ & $\begin{array}{l}71.08^{\mathrm{c}} \\
\pm 1.86\end{array}$ & $\begin{array}{l}98.23^{\mathrm{b}} \\
\pm 2.06\end{array}$ & $\begin{array}{l}121.57^{\mathrm{a}} \\
\pm 1.21\end{array}$ & $\begin{array}{l}68.97^{\mathrm{c}} \\
\pm 2.28\end{array}$ & $\begin{array}{l}98.93^{\mathrm{b}} \\
\pm 1.71\end{array}$ & $\begin{array}{l}128.12^{\mathrm{a}} \\
\pm 2.29\end{array}$ & $\begin{array}{l}63.90^{\mathrm{c}} \\
\pm 0.94\end{array}$ & $\begin{array}{l}98.37^{\mathrm{b}} \\
\pm 4.40\end{array}$ & $\begin{array}{l}141.34^{\mathrm{a}} \\
\pm 10.10\end{array}$ & $* *$ & $* *$ & $* *$ \\
\hline $\begin{array}{l}\text { Sale price }(\mathrm{Tk} / \mathrm{kg} \\
\text { bird) }\end{array}$ & $\begin{array}{l}85.00 \\
\pm 0.00\end{array}$ & $\begin{array}{l}120.00 \\
\pm 0.00\end{array}$ & $\begin{array}{l}130.00 \\
\pm 0.00\end{array}$ & $\begin{array}{c}85.00 \\
\pm 0.00\end{array}$ & $\begin{array}{l}120.00 \\
\pm 0.00\end{array}$ & $\begin{array}{l}130.00 \\
\pm 0.00\end{array}$ & $\begin{array}{l}85.00 \\
\pm 0.00\end{array}$ & $\begin{array}{l}120.00 \\
\pm 0.00\end{array}$ & $\begin{array}{l}130.00 \\
\pm 0.00\end{array}$ & - & - & - \\
\hline $\begin{array}{l}\text { Net profit }(\mathrm{Tk} / \mathrm{kg} \\
\text { bird) }\end{array}$ & $\begin{array}{l}13.92^{\mathrm{b}} \\
\pm 1.86\end{array}$ & $\begin{array}{l}21.78^{\mathrm{a}} \\
\pm 2.06\end{array}$ & $\begin{array}{c}8.43^{\mathrm{c}} \\
\pm 1.21\end{array}$ & $\begin{array}{l}16.03^{\mathrm{b}} \\
\pm 2.28\end{array}$ & $\begin{array}{l}21.07^{\mathrm{a}} \\
\pm 1.71\end{array}$ & $\begin{array}{c}1.88^{\mathrm{c}} \\
\pm 2.29\end{array}$ & $\begin{array}{l}21.11^{\mathrm{a}} \\
\pm 0.94\end{array}$ & $\begin{array}{l}21.63^{\mathrm{a}} \\
\pm 4.40\end{array}$ & $\begin{array}{c}-11.34^{b} \\
* \\
\pm 10.10\end{array}$ & $* *$ & $* *$ & $* *$ \\
\hline
\end{tabular}




\section{Conclusions}

On the basis of results of productivity, it was concluded that commercial broiler, cockerel and cross-bred chicks could be reared upto 28,56 and 63 days respectively to reach target weights close to 1250,850 and $850 \mathrm{~g}$ respectively to obtain maximum profit. Future research works to generate more information on these genotypes of birds may be useful for small farmers. Since the current study was conducted in farm condition, a study of this nature under field condition would be helpful. Year round profitability of commercial broiler, cockerel and cross-bred ( $F_{1}$ RIR $\hat{\sigma} \times$ Fayoumi $q$ ) yet to be determined independently so that small farmers can be suggested to select the right type of bird to rear up to right target weight throughout the year. In addition, differences in the quality of meat such as texture, tenderness, juiciness etc resulting from variation in genotypes may be investigated.

\section{Literature Cited}

Ahmed, S. U. 1999. Performance of different strains of broilers in rainy, winter and summer seasons of the year. BAU Res. Prog., 10 : 94-95.

Ahmmad,K. 2005. Poultry Business Guide. Poutry Khamar Bichitra, Dhaka, Bangladesh.

Amber, M. A. J., Bhuiyan, A. K. F. H., Huque, M. A. and Amin, M. R. 1999. Ranking of some pure and cross-bred chicken using scoring indices. Indian J. Poult Sci., 34(2) : 140-146.

Amber, M. A. J. 2000. Rural Poultry Breeding. Guide for training of trainers $\left(4^{\text {th }}\right.$ edition), PLDP. Bangladesh.

Anisuzzaman, M. 1988. A study on growth rate, feed efficiency and livability of Fayoumi chicken under Bangladesh condition. MS Thesis, Dept. of Poult. Sci. Faculty of Animal Husbandry, Bangladesh Agricultural University, Mymensingh.

Azharul, I. M., Ranvig, H. and Howlider, M. A. R. 2005. Comparison of growth rate and meat yield characteristics of cockerels between Fayoumi and Sonali under village conditions in Bangladesh. Livestock Res. Rural Devt., 17(2) : Article 21.

BRAC (Bangladesh Rural Advancement Committee). 2005. Report on poultry farms.

Chowdhury, S. D. 2003. Development of least cost feed formulae to improve productivity of semiscavenging poultry birds. Final Report, Participatory Livestock Development Project, DANIDA. Dept. of Poult. Sci., Bangladesh Agricultural University, Mymensingh.

Cobb-500, 2004. Commercial Broiler Management Guide. The Cobb Breeding Company Ltd. East Hanningfield, Chelmsford, ESSEX, CM3 8BY, United Kingdom.

DLS (Department of Livestock Services). 2005. Report on parent stock import.

Himanshu, P. C., Chandramoni and Prasad, A. 2004. Effect of full fat soya on the performance of cockerel. Indian J. Anim. Sci., 21 : 210-212.

Hauqe, Q. M. E., Mostari, M. P. and Islam, M. R. 2005. Production and marketing age of male layer chicks in Bangladesh. Proceedings of the Seminar, $4^{\text {th }}$ International Poultry Show and Seminar, 10-12 march 2005 at Bangladesh China Friendship Conference Center (BCFCC), Sher-e-Bangla Nagar, Dhaka, Bangladesh. pp. 70-76. 
Bang. J. Anim. Sci. 2008, 37(2)

Islam, M. S., Alam, M. R., Rashid, M. A. and Hossen, M. J. 2006. Effect of balanced supplementary feed and cafeteria feeding on the performance of cross-bred chicken in semi-scavenging system. Bang. J. Anim. Sci., 35(1-2) : 36-41.

Kabir, S. S. K. 2005. Poultry in Bangladesh; Awaiting the awakening. Proceedings of the Seminar, $4^{\text {th }}$ International Poultry Show and Seminar. 10-12 March, 2005. Dhaka, Bangladesh. pp. 8-15.

Mamun, F. A. 2003. A comparative study on the performance of cockerels of two different laying strains under farm condition. M. S. Thesis, Dept. of Poult. Sci. Faculty of Animal Husbandry, Bangladesh Agricultural University, Mymensingh.

Masic, B. and Khalifah, M. 1965. The conformation of chick of various breeds and crosses for broiler production. Anim. Breed. Abstr., 34(1): 114.

Rahman, M. M., Baqui, M. A. and Howlider, M. A. R. 2004. Growth performance and meat yield of reciprocal crosses of RIR and Fayoumi chicken under local condition of Bangladesh. Bangladesh vet. J., 21(1): 45-51.

Roy, K. R., Chowdhury, S. D., Sultana, N., Moshad, M. A. A. and Hasan, M. N. 2006. Production potentiality and economics of rearing cockerels from a commercial layer strain. Bangladesh. vet. J., 23(2): 83-87. 